\title{
8 Translation and Institutional Change: What Happened when Participatory Budgeting Came to the Nordic Countries?
}

'Participatory budgeting' (PB) is a term used for the proposal that ordinary citizens and not elected politicians should decide on how to spend public funds. The idea and practice of PB emerged in Brazil in the early 1990s but has since travelled to thousands of municipalities across the globe, among them cities such as Paris and New York. As it has spread, however, its content and form have altered. Whereas PB originally denoted reforms that challenged representative political institutions, it now stands for schemes and projects that seek to strengthen them. This is because PB has been translated and given new meanings in the places it has travelled to. Today, PB is normally presented as a form of 'good governance' or citizen consultation and not as a comprehensive reform to alter local political institutions. The practice has also changed. In the original PB all municipal investments were distributed through a participatory process, but in cities like New York and Paris only a fraction of the funds are set aside for local residents to decide.

In Nordic countries, PB has been introduced as a project that encourages particular segments of the population to engage in conventional politics. This translation has not led to fundamental institutional change but has rather only added layers to pre-existing arrangements. There are at least two explanations for this. One is that the conditions that nourished PB in the first place are absent in the Nordic countries. PB was born at a time when the Brazilian public had very little confidence in state institutions, and there existed a massive popular movement that advocated participatory democracy as an alternative to the status quo. In the Nordic countries, to the contrary, confidence in public institutions is relatively high, and most movements work within the established institutional order. The other explanation is that settled institutions exert a strong pressure on how imported ideas and practices are translated. The rules that regulate representative democracy are very strict in the Nordic countries, and those who defend them are well situated to block challenges to existing institutional arrangements. In this chapter I will illustrate these two explanations for the trajectory of PB in the Nordic countries by looking at Fredrikstad - a mid-sized city in southeast Norway that introduced PB in 2009.

\subsection{Translation, Institutions and Change}

First some words on the analytical perspective that informs this study and the method used to conduct it. The travel of ideas or policies - like PB - is often studied within 'policy diffusion' or 'policy transfer' frameworks (Dolowitz \& Marsh, 2000; Simmons, 
Dobbin, \& Garrett, 2006). These are concerned with the mechanisms with which policies travel or with the structural forces underlying their diffusion but also with how they are implemented in new places. Such research rarely argues that foreign institutions and practices are adopted in toto. Cut and paste transitions are seen as exceptions, and hybridized combinations of outside and local knowledge are more common. Local differences may alter the speed, scope and extent to which outside practices are incorporated. Some actors are always more interested in pushing transfer processes, and certain actors are more receptive to them than others (Marsh \& Sharman, 2009, p. 279). But what these perspectives lack is often a view of how ideas themselves change as they travel from one place to another (Mukhtarov, 2014). As Bruno Latour writes, 'the spread in space of time of anything - claims, orders, artefacts, goods' is in 'the hands of people' who 'may act in many different ways, letting the token drop, or modifying it, or betraying it, or adding to it, or appropriating it' (Latour, 1986, p. 267). That is why ideas are not simply received, rejected, resisted or accepted - they are translated (Latour, 1991, p. 116). To understand the changes that occurred with PB as it came to the Nordic countries, I therefore turn to what is called translation theory in 'Scandinavian institutionalism' (Czarniawska \& Sevón, 1996; Røvik, 2016; Sahlin \& Wedlin, 2008; Scheuer, 2008a; Wæraas \& Agger Nielsen, 2015).

When ideas and practices travel they are first decontextualized from their original location and then recontextualized into a new one. This opens the idea to a great deal of interpretation and alteration. Translation theory emphasizes that these interpretations and alterations are not arbitrary but rather bound by certain rules. Røvik speaks of three modes of translation with associated rules. The reproducing mode of translation refers to deliberate attempts to replicate practices in the source context. Copying is the rule within this mode. These are actions 'that aim to replicate in a recipient context certain practices and/or results found in a source context. Thus, copying denotes attempts to achieve a success similar to that observed in the source context by using the exact same means in a new location' (Røvik, 2016, p. 8). The modifying mode of translation is more pragmatic and happens where translators both try to include central elements of the desired source practice in the translated version as well as to adjust them to work within the recipient context. There are two rules in this mode: addition and omission. Addition involves adding elements to the source version when it is being translated to a new context. Omission refers to toning down or omitting certain aspects of the source version in the recipient context. Both rules can be applied in the same settings since source and recipient contexts might be similar in certain aspects but different in others. The radical mode of translation takes place when translators consider themselves relatively unbound by the prototype when they implement a new practice in their own context. The editing rule within this mode is alteration - the 'comprehensive transformation and mixing of one or more source versions of a practice, leading to the creation of a unique version in the recipient organization' (ibid., p. 9). The use of these rules is 
decided by certain conditions, such as how embedded the practice is in the source context or how transformable the transferred knowledge is. The most important condition in this discussion, however, is the degree of similarity between the source and recipient contexts. If they are very similar, copying is the most appropriate rule. If they are moderately similar, adding or omitting is common. If the contexts are very different in variables crucial for the functioning of the practice, it is more likely that the transferred idea is domesticated and presented as an innovation rather than an imitation or modification (ibid., p. 14). As I will show, the content of PB has slowly changed as time progressed and as PB has moved to new contexts that lack the factors that were crucial for its implementation. PB as practised in the Nordic countries and Fredrikstad is a product of this journey.

Another important concept in translation theory is that of an editing infrastructure. People who wish to introduce a new practice in their organization or community can seldom do so by replication. They have to relate to the conditions in the field (Scheuer, 2008b, p. 161). These conditions are partly bound to the way people are thinking and the norms for behaviour. As Sahlin and Wedlin write, when 'reforms and experiences are accounted for and narrated, they tend to be framed and presented in familiar and commonly accepted terms so that they will make sense to a reader or listener. [...] These concepts, references and frameworks form the infrastructure of editing and they restrict and direct how the accounts are given' (Sahlin \& Wedlin, 2008, p. 225). Translators have to align their projects with certain 'master rules', position them within existing categories and thought-schemes and draw upon available discourses to make them meaningful to others (Hardy \& Maguire, 2008, p. 208). The editing infrastructure refers to what Scott has called the cognitive and normative pillars of institutions. The cognitive pillar emphasizes how institutional rules make up frames through which meaning is made, and the normative pillar describes how these rules define values, roles and appropriate forms of behaviour (Scott, 1995, pp. 37-38, 40). As I will show, the cognitive and normative pillars of representative democracy exerted a strong influence on the translation of PB to Fredrikstad.

What the concept 'editing infrastructure' should also include is what Scott calls the regulative pillar of institutions. This has to do with processes that 'involve the capacity to establish rules, inspect or review others' conformity to them, and as necessary, manipulate sanctions, rewards or punishments' (ibid., p. 35). This is the hard power of institutions - something that translators are expected to adapt to if they are to succeed in introducing a new practice. The opportunity for success depends, for example, on the strength of the veto power of those who defend the established institutions and the possibility for bending its rules (Mahoney \& Thelen, 2010, p. 18). If budgeting rules are malleable or the political establishment is weakened, it could be possible to introduce a radical version of PB. If not, the translation most likely to succeed would be a more moderate one. This does not necessarily mean that change is impossible within such a setting. Revolution 
and the displacement of existing institutions with brand new ones is not the only form of change that can occur. Small-scale, gradual and unnoticeable change can occur when new institutions or rules are added alongside existing ones. Mahoney and Thelen call this layering and argue that even though powerful veto players can protect old institutions, they cannot necessarily prevent the addition of new elements to them (ibid., p. 20). The introduction of PB in the Nordic countries must also be understood to occur within such a setting, which effectively narrowed down its range of possible translations.

A weakness with this perspective is that it can easily send the impression that a translation is preordained, depending on the field in which it is implemented. Institutional fields are not totalizing phenomena. They are riven with inconsistencies and conflicts, something that provides opportunities for institutional change (Hardy \& Maguire, 2008, p. 203). The form and content of translations cannot therefore be decided a priori but instead are 'primarily an empirical question to be resolved by studying the introduction of a practice into a particular context' (Wæraas \& Sataøen, 2014, p. 245). The task of the researcher is therefore to describe the translation, identify what rules are used and seek explanation for them. This is what I do with PB in Fredrikstad in this chapter. The method I have used is text analysis. I have identified documents where the translation of $\mathrm{PB}$ appears and analyzed these using the tools discussed above. The documents studied are both internal and external and encompass a PB-brochure, flyers that encourage citizens to participate, website definitions, contributions to newspapers from municipal staff and PowerPoint presentations given to other municipalities or official institutions. Translations in larger organizations are normally objectified in written documents (Sahlin \& Wedlin, 2008), and people who want to change institutions mainly communicate with audiences through the production, distribution and consumption of texts (Hardy \& Maguire, 2008, p. 208). The strength of the text analysis is that it captures this official translation work. The weakness of it is that it may miss out on the unofficial and oral translations that go on in such settings as well as the political and organizational play of the field actors that lies underneath the translation process.

One final note on my approach is that I do not look to judge how true or untrue the translation of PB in Fredrikstad is to the original version that emerged in Brazil in the early 1990s. According to some definitions (see for example Wampler, 2012) most examples from the Nordic countries would probably not count as PB. I have been myself walking the streets of Oslo collecting signatures to introduce PB in my city, and I can understand the pain that many feel when they see what they perceived as an emancipatory project be translated into something radically different. In this analysis, however, I follow Spinoza's dictum of non ridere, non lugere, neque detestari, sed intelligere (not to laugh, not to lament, not to curse - but to understand) and leave the politics aside for another occasion. What is crucial here is to understand why PB has been translated as it has. 


\subsection{From Porto Alegre to Fredrikstad}

Before it came to the Nordic countries and Fredrikstad, PB had already undergone a long journey. It was first initiated in Porto Alegre in southern Brazil when a socialist alliance led by the Workers' Party (PT) won the municipal elections in 1989. Together with community organizations and local social movements, the new municipal administration pursued a participatory democracy model inspired by socialist ideas of workers' councils and Christian Base communities from the progressive branch of the Catholic Church. In its original format participatory budgeting meant that all adult citizens could participate directly in allocating all of the municipality's investments. Typical projects would range from connecting neighbourhoods to the running water network, paving roads, upgrading sanitation systems, renovating schools or establishing a health clinic, computer lab or kindergarten. The new budget institutions combined direct participation and representation. The direct participation took place in open assemblies where residents would come forth with investment proposals and vote on how to prioritize the money. The participants would then elect delegates and councillors to represent them in negotiations with the municipal administration and the make-up of the final investment proposition. The new budgeting rules never formally supplanted the representative political institutions in Porto Alegre, but they undermined the authority of the local legislative assembly. PB was commonly perceived as more transparent and just than the patron-client relations that up until then had dominated local politics. The opposition was also weakly organized and not able to veto the outcomes of the budget process (Abers, 2000; Baiocchi, 2005; Goldfrank, 2011; Gret \& Sintomer, 2005).

The PB institutions transformed Porto Alegre. They improved government transparency and reduced corruption (Goldfrank, 2011, pp. 231-237) and redirected public resources to working-class neighbourhoods and marginalized sectors of the population (Marquetti, 2008). Segments that previously were disengaged from politics - like women with low income and little formal education living in the outskirts of the city - became mobilized to participate actively on budget issues (Fedozzi et al., 2013). These changes received worldwide attention. Development agencies such the UN and the World Bank adopted PB as a best practice of urban good governance. The global social movement gathering 'World Social Forum' hosted by Porto Alegre gave participatory budgeting an iconic status to the international Left. It was also widely studied and disseminated in academic circles where it was described in very positive terms as a 'redistributive democracy' (de Sousa Santos, 1998), a case of 'empowered participatory governance’ (Fung \& Wright, 2003), an 'empowered participatory regime' (Baiocchi, 2005) and even a 'real utopia' (Wright, 2010).

One of the reasons why Porto Alegre became an emblem of participatory democracy was that it not only consulted citizens but also gave them real power in deciding the distribution of municipal funds. According to Baiocchi and Ganuza (2014) it had both a communicative and an empowering dimension. The communicative dimension 
rested on public forums that were established to discuss the budget, whereas the empowering dimension was based on institutions that ensured that the outcomes of these deliberations were realized by the municipality. The empowerment dimension, however, is rarely found in any of the thousands of cases of PB found on a world-wide basis today (Dias, 2014; Gilman, 2016; Sintomer, Herzberg, \& Röcke, 2008). In Paris, for example, the municipality has allocated $€ 500$ million from 2014 to 2020 to projects that have been proposed and elected by citizens. In New York, city districts are allowed to initiate PB if they set aside $\$ 1$ million for the process. These funds are extremely small compared to the overall investment levels in these cities, and they have not been accompanied by wider reforms to transform the administrative structure of the government to ensure that the outcomes of citizen deliberations become policies. In general, the version of PB that has travelled the world has been one with a focus on 'good government' rather than institutional change and is often found in 'piecemeal fashion or as an overly simplified template for citizen consultation, devoid of any broader radical agenda to transform state-society relations from below, or even to fundamentally alter resource distributions' (Peck \& Theodore, 2015, p. 214).

The type of PB that was introduced in the Nordic countries came at a time when the concept had already undergone substantial alterations. Sweden was first among the Nordic countries to initiate what they called 'citizens' budgets' in several municipalities at the local level starting around 2006 (Sveriges Kommuner och Landsting, 2011, Ch. 4). This was followed by several local initiatives in Denmark (Bregenov-Larsen, 2016), one undertaking in Finland (Oikkonen, 2012) and also in Reykjavik, the capital of Iceland (Grímsson \& Bjarnason, 2016). PB came to Norway when an alliance of left-wing groups and community associations in Oslo petitioned the city government to do a PB-trial (Bystyret i Oslo, 2005). Even though it was unsuccessful, it was soon followed by other advocates. In 2009, a Cabinet Minister from the Socialist Left Party (Sosialistisk Venstreparti) co-authored a book claiming that participatory budgeting would make Norwegian politicians more accountable and improve budget priorities (Lysbakken \& Skjerve, 2009, p. 204). The centre-left government of which he was part also encouraged municipalities to experiment with participatory budgeting as a way of facilitating increased participation from citizens in local issues (Regjeringen Stoltenberg II, 2009, p. 30). The Norwegian Association of Local and Regional Authorities (KS) has stated that participatory budgeting is a policy tool they recommend as long as a portion of the budget is specifically set aside for this purpose (Kommunesektorens organisasjon, 2013, p. 31). Participatory budgeting has even been adopted by conservatives. The current right-wing government refers to it as a good practice to engage citizens in small towns who merge with others to form larger municipalities (Regjeringen.no, 2015). Fredrikstad, however, is the only municipality in Norway that has explicitly introduced PB. Although PB did not come by accident to the Nordic countries - as the relatively broad outreach of PB in political debate in Norway and the many cases in Sweden and Denmark illustrate - it did arrive in Fredrikstad partly by coincidence. In 2008 the municipality was invited 
to join an EU-funded project with Uddevalla - a Swedish town that took interest in Fredrikstad's community funding scheme. The aim of the project was to experiment with new methods to engage citizens in municipal politics. Through this cooperation, Fredrikstad was included in a network of Swedish municipalities which received training from European experts on how to implement and organize PB.

This led to the implementation of three different PB projects in Fredrikstad over a six-year period. The first took place quite soon after Fredrikstad joined the PB network. In 2009, youths aged 13 to 19 were invited by the municipal administration to propose ideas on how to spend 200,000 NOK (around 22,500 euro) on projects for youngsters in the city. The ideas were transformed into workable projects by the youths themselves and then put to a vote among all pupils at the city's lower and upper secondary schools. The winner was a so-called 'LAN party' - a gathering where kids can bring their own computer equipment and play multiplayer games. A total of 61 per cent of the city's pupils voted (Fredrikstad kommune, 2010, p. 6; Oliveira \& Allegretti, 2013, pp. 17-19). In 2013 a similar process was initiated for active skateboarders. The municipality gave the local skateboarder association 200,000 NOK to construct new ramps in their skate hall. The municipality facilitated a participatory process where skaters elaborated the design proposals and voted on them online (Syversen, 2013; Ystgaard, 2013). The most recent PB event took place in 2015 when residents in a local community surrounding a city square - including children from the kindergartens and the primary school - were invited to propose how the square should look after it was renovated. The municipality gave 800,000 NOK (around 91,000 euros) to the renovation. In total 260 people from the local community participated in designing the proposals, and 235 people voted. More than two-thirds of the voters were less than ten years old (Eidsvold, 2014, 2016; Holøien, 2015).

These projects did not lead to fundamental institutional changes in Fredrikstad. As Scheuer (2008a, p. 112) argues, travelling ideas can have institutional impacts in a recipient context if they are translated into objects, then to actions and finally to institutions if the actions are repeated regularly. However, PB in Fredrikstad did not happen on a regular and predictable basis but instead remained on an ad-hoc action level. At no point did these actions challenge the established political institutions. The youth and skateboard projects hardly used money from the municipal budget. In the city square renovation project, which was the most ambitious of the three, the elected politicians had already decided that the 800,000 NOK should go to the renovation. What the participating community members could decide was how the park should look. The rule that municipal budgeting is the responsibility of elected officials in the city council was never replaced. On the other hand, the PB projects can be said to have opened up the opportunity to also handle public funds in a participatory fashion - opportunities that had not been formulated and only partly utilized in Fredrikstad before they became aware of the concept of PB. As such, the PB in Fredrikstad can be understood as a form of layering, where new informal rules of how to handle public money were added to pre-existing formal ones. This feature is shared by the other 
Nordic countries, where PB is now and then used to give certain communities extra influence in regard to how money is spent within certain public works or services. The only exception from this is Reykjavik, where the inhabitants have been able to distribute around €1.9 million annually since 2012.

\subsection{A Toolkit Version of PB}

Fredrikstad's PB looked very different from the original experiences in Porto Alegre because it was translated to mean something else as it came to the city. One thing shared by all translations is that ideas and practices are objectified and turned into accounts or materializations when they travel (Sahlin \& Wedlin, 2008, p. 225; Scheuer, 2008b, p. 161). Part of this objectification consists of turning the idea or practice into a linguistic artefact such as, for example, a label (Czarniawska \& Sevón, 1996, p. 32). To make objects transferable, time- and space-bound features are excluded. If the source and recipient contexts are very different, local prerequisites are omitted. The practice is distanced and decoupled from time and space (Sahlin-Andersson, 1996, pp. 85-86). The story of how and why the idea or practice came about in the first place is reconstructed. What might have been very chaotic, incidental and diffuse is presented as rational. Previous experiences are scientized or theorized. Actors are described as purposeful and procedures and effects as logical outcomes of their intentions (Sahlin \& Wedlin, 2008, p. 226).

In Fredrikstad, PB was labelled 'Deltakende budsjettering' - the labelling underscored by the use of the capital ' $\mathrm{D}$ ' (which equals 'Participatory budgeting' with a capital 'P' in English) (Fredrikstad kommune, 2010, 2013). Instead of being understood as a particular model or set of reforms - as was the case in Porto Alegre it is rather understood as an umbrella term for a range of methods that include citizens in decisions regarding tax money. A central document describing Fredrikstad's PB emphasizes that it is not necessary to include the whole investment budget in the process to qualify as PB. It is sufficient to use only a certain portion, regardless of how big it is. Nor do decisions regarding this portion need to be binding. They may only be advisory. Thus, the document does not single out only one method as PB but states that it involves a range of solutions and possibilities. The analogy which is used is a tool kit with a variety of tools (Fredrikstad kommune, 2010, pp. 1, 3; 2013). This definition opens up for a very wide range of practical expressions of $\mathrm{PB}$, and it also frees those who want to adopt it from any bonds to previous experiences.

Translations are often dramatized as they are introduced into new settings: concepts, categories, examples, references and ideological frameworks are used to structure, narrate and make sense of the ideas or practices that are translated (Sahlin \& Wedlin, 2008, pp. 226-227). In Fredrikstad, the concept of 'Deltakende budsjettering' was repeated in internal as well as external communications - in brochures, on the city's website, in presentations to other authorities and in contributions to newspapers 
as well. The dramatization of PB is that of a policy invention with global success. The story that is told is that PB used to be tied to a certain context, but because of its great achievements it spread out to ever more regions and was transformed in such a way that it became suitable to any place that wishes to develop democracy further. Several examples are used to underscore this point. One is the Bertelsmann Foundation's prize to the 'world's best municipality', which was awarded to a town in New Zealand that involved its inhabitants in deciding budget priorities. Another is the fact that PB is now utilized in 'a majority of European countries' and that even the British parliament issued a report 'inviting all public enterprises' to introduce PB (Fredrikstad kommune, 2010, p. 3).

The success story not only has its heroes but also villains in the form of dangers that can be realized if PB is not adopted in the right manner. Lobby groups, for example, can attain too much influence, public expenses can increase, decisionmaking processes may be drawn out and irrelevant themes and priorities can be put on the agenda. However, these are classified as only possible pitfalls or 'challenges that have to be handled', and research comes to the rescue with certain guidelines (or success factors) for what to do (ibid., pp. 4-5). There is also a story of local success told in the document, which is the one of the implementations of PB in Fredrikstad. After going through different PB projects in other parts of the world, the document turns its attention to the first PB experience with the students in the city. It claims that 'nowhere in the world has there been a youth project where Participatory Budgeting has been used as a method where the voter turnout has been so high' (ibid., p. 6). Moreover, it is noted that even though PB is an idea imported from abroad, it already has a predecessor in Fredrikstad in the community-funding scheme. This adds an element of familiarity to $\mathrm{PB}$, which might disarm criticism that it is something foreign that does not fit into Norway - it is not so different from what we are already doing after all. As a whole, the translators used what Sahlin and Wedlin (2008) call rules of logic and formulation to decontextualize PB and to tell a success story of an innovation that could easily be adopted in a Norwegian city.

\subsection{Modifying a Pre-Existing Translation}

One of the reasons why this toolkit version of PB had to be presented as a near universal was that the conditions that nourished the original PB were absent in Fredrikstad. The research literature on Porto Alegre (as well as other Brazilian cities) points to a number of factors that were necessary for its successful implementation and persistence. These included the extensive decentralization of fiscal powers to the municipal government, an ideological commitment among the leading political party to establish a new form of government, a strong mayoral government that gave the municipal administration power over elected politicians, civil society organizations who shared the vision of a new society and were able to educate and mobilize citizens 
to become empowered participants in the new institutions and very low levels of public confidence in established institutions (Abers, 2000; Baiocchi, Heller, \& Silva, 2011; Goldfrank, 2011; Wampler, 2007). All of these factors combined constituted a very peculiar combination that existed only in some cities in the south of Brazil in the early 1990s (Avritzer, 2006). Virtually all of these factors were absent in Fredrikstad when PB came to Norway. The spending of the municipality was heavily directed by national policies and regulations, no major political party was committed to transforming the local government, the mayor and the municipal administration were subordinated to the elected politicians and civil society organizations did not mobilize large number of citizens nor demand anything like PB. The only faint similarity was that confidence in the local government was fairly low. Among other things, a majority of the population felt that the politicians disrespected the view of the citizens and that special interests were prioritized over common interests (Kommunesektorens organisasjon, 2010).

Since the contexts were very different on variables that were crucial for PB, the translation was radically different compared to Porto Alegre. Thus, alteration might seem to be the rule applied in Fredrikstad. The translators were unbound by the prototype in Porto Alegre and did not describe it as a model for Fredrikstad. Instead Porto Alegre and other examples from Latin-America were framed as part of the prehistory of PB in a different and developing part of the world (Fredrikstad kommune, 2010, p. 7). The municipality in Fredrikstad did not target all citizens as in Porto Alegre but rather specific groups such as the youth and skateboarders. They also used external funds or only a small fraction of the budget for participatory projects as opposed to all municipal investments in the original format. But to say that alteration was the rule in Fredrikstad only makes sense if the translation was done directly from Brazil to Norway. It was not. The Fredrikstad experience is better understood as a product of a long chain of translations that started in Brazil, moved on to other countries in Latin-America and finally came to Europe and the Nordic countries. The content and meaning of PB had already been altered on this journey because these contexts were already very different from that of Brazil. PB-advocates in Fredrikstad did not do the translation work by themselves but instead together with other municipalities inside the Swedish PB network. The main PB document in Fredrikstad is largely a copy of a PB fact sheet from this network, where the focus was on places other than Brazil. The examples used in the publication were from Portugal, where a municipality involved young people improving their school environment, as well as Sweden, where a suburb to Stockholm allowed citizens to vote on how to spend money to upgrade their physical environment (Sveriges Kommuner och Landsting, 2010). The network also organized tours to other municipalities with PB, and representatives from Fredrikstad went to Seville in Spain to see the practice for themselves (Oliveira \& Allegretti, 2013, p. 19).

The disembedding of PB from Porto Alegre and Brazil had, in other words, already been done by others before Fredrikstad. Moreover, the diverse set of practices that used the PB term had already provided a very different basis to translate from than if 
the focus had been on Brazil. It is therefore more appropriate to say that Fredrikstad moved within the modifying mode of translation, where the translators tried to both include central elements of the source practice in the translated version and to adjust it to fit within the recipient context. The most important source practices for Fredrikstad were not those found in Brazil but rather the examples found in Europe. In addition, they could also look to the many other Swedish municipalities who implemented PB simultaneously (Sveriges Kommuner och Landsting, 2011, pp. 21-54). These examples, however, had not been described in detail, which meant that there were many nonexplicit aspects in these practices that the translators in Fredrikstad related to. This opened up the possibility to add elements to the model - such as specific target groups that politicians and administrative staff found it important to reach - or pre-existing concepts like 'Youth Entrepreneurship', which was used to develop investment ideas into feasible projects. Due to the many models and examples to choose from there was no need to tone down or omit aspects of specific source versions. Instead, this was indirectly done through selecting those that were most convenient for Fredrikstad. The toolkit definition of PB that Fredrikstad inherited lent it easily to additions and omissions: as long as some part of the population was involved in discussions about the use of public funds, it was not so important how they did it. Lastly, the differences between the contexts of other European PBs and that of Fredrikstad were not especially significant. This made it easy for the translators in Fredrikstad to identify with the motivation for introducing participatory budgeting - such as the emphasis on developing democracy further and creating more effective administrations but also to add elements that were specific to their own context. One of the most important aspects that was added was the inclusion of the pre-existing community funding scheme in the description of what could be called PB.

\subsection{Supporting Representative Democracy}

The success of translations depends on the number of people acting on their behalf (Scheuer, 2008a, p. 127). Translators need to mobilize other groups and individuals to support their proposal, and one way to do so is to present ways of thinking that can get people to act together. This is often referred to as 'collective action frames' (Tarrow, 1998). Such ways of thinking typically consist of the following elements: punctuation identifies a problem and defines it as important, diagnosis elaborates the problem and describes who or what is responsible for it, prognosis describes what is required to correct the problem and finally motivation encourages actors to participate in the change (Hardy \& Maguire, 2008, p. 208). Here, the concept of editing infrastructure comes in. On one hand translators wish to introduce something new, but they also need to do so in a way familiar enough for people to gain their support - they have to relate to underlying concepts, categories, values etc. One way to do so is to frame the proposals within the cognitive and normative pillars of established institutions. 
The main translation document in Fredrikstad should be understood as an attempt at this. The document defines decreasing participation, sinking party membership and increasing distrust in public institutions as the main problems that have to be solved (punctuation), and it indirectly puts the blame on the lack of dynamism in the political system (diagnosis). At the same time it emphasizes that there are innovations such as PB that create win-win situations for everyone involved - not least the municipal administration and local politicians (prognosis). Finally, the document tries to evoke fear in those who read it that the state of democracy can evolve into a much graver situation if nothing is done and uses the global success of $\mathrm{PB}$ as a hope for a more optimistic future (motivation). This way of framing PB does not challenge the established institutions but rather speaks about upgrading and neutralizing the threats to them (Fredrikstad kommune, 2010). It is directed to an internal audience in the municipality - elected politicians and the municipal administration - and tries to convince them that $\mathrm{PB}$ is a good idea.

But the editing infrastructure cannot be understood as one unitary system of facts and values dictated by established institutions. Institutional fields are not totalizing phenomena but are rather riven with inconsistencies and conflicts. Translators must bear in mind these tensions when they try to mobilize support (Hardy \& Maguire, 2008, pp. 203-204). Only providing one version of the translation might be risky if support from various groups is needed in order to be realized. One such inconsistency is the difference in values and ways of thinking about democracy. Democracy can mean different things for different groups in society and be associated with a diversity of discourses and values. It is likely that politicians and administrative staff primarily associate democracy with representative institutions, whereas citizens at large associate democracy with the right of everyone to be heard and affect outcomes. Politicians are likely to attach values such as reliability and responsibility to representative institutions, whereas as the general population are prone to attach other values such as responsiveness and effectiveness to them. These differences might be a source of tensions. One example is a survey conducted in Fredrikstad where 88.7 per cent of the politicians agreed that elected officials considered the views of the inhabitants, and only 36.8 percent of the general population thought the same (Kommunesektorens organisasjon, 2010, p. 20). The external communication was framed differently than the internal documents. Instead of focusing on the perceived benefit for the municipality or its political system, it focused on the right of individuals and communities to be heard in the political process. In the youth project, for example, the participants were encouraged to suggest something that could make Fredrikstad 'more fun,' 'nicer,' 'more environmentally friendly' or 'safer' for themselves. As a group, they were asked to come up with new ideas to enhance the life quality of the youth in the city (Fredrikstad kommune, 2009). In the square renovation project the municipal administration emphasized that the park belonged to the residents. They acknowledged that nearby residents had wanted to improve it and that they would be affected by noise and logistical problems while the renovation 
was going on. Thus, as the municipal organizer told the residents in a communication to a local newspaper, 'that it makes it even more important to have a place that is your own. Because you will decide about the square' (Eidsvold, 2014). Nevertheless, even though the external communication spoke to a different set of values and ways of thinking about democracy, at no point did it dispute the legitimacy of the representative institutions. It rather underscored that representative institutions could be supplemented by other modes of engagement without antagonism. As such, the concept of PB and the way it was framed moved well within the cognitive and normative pillars of representative democracy.

\subsection{Layering as the Best Available Option}

Translators also need to adapt to the regulative pillar of institutions if they are to succeed in introducing a new practice. Two important aspects here are how flexible the rules of the established political institutions are and how strong the position of institutional defenders is (Mahoney \& Thelen, 2010). In Fredrikstad the translators found themselves in a situation where there was little room to interpret the rules of how budget decisions should be made and where it was not possible to allow any slack in enforcing them. These rules are regulated by law in the national Local Government Act, which does not leave any room for discretion. The act states that it is only the municipal council that consists of elected politician who can make decisions on how to allocate the city budget. How strict these rules are can for example be observed in the reactions from government institutions when they perceive threats to the budget authority of the municipal council or sub-municipal councils which may also decide a portion of the budget according to the law. In 2008 a city-district in Oslo, Norway's capital, told the city government that they wanted to introduce PB. They asked for a statement from the juridical department of the city government but got as a reply that it is illegal to give decision-making powers over public funds to popular assemblies and that it would not allow it. Furthermore, the city district was told that even if it wanted to try out the method with merely a small sum of money, they nevertheless had to apply to the national government for a temporary exemption from the Local Government Act. All continuation of this work had to be stopped until such permission was given (Kallmyr \& Andersson, 2008). Although Fredrikstad is not a city district that has to wait for statements from the city government, it is still overseen by higher state authorities and could be sanctioned if it deviates from the rule that only the municipal council can make decisions regarding the local budget. Instead, the advocates of PB in Fredrikstad are better understood as a small group of institutional entrepreneurs trying to bring about change in the municipal administration from within.

This is related to the veto power of institutional defenders. In the case of Fredrikstad these had access to the juridical system that can prevent municipalities 
from breaking national regulations. Closer by, however, was the sanction power of the municipal council in Fredrikstad itself. When the youth PB project was executed, the only political party that actively supported PB in its programme - the Socialist Left party (SV) - had just two representatives on the municipal council. The institutional defenders were therefore in a majority in Fredrikstad, and any proposal to change the rules of how the budget was made would have easily been vetoed locally. In such a situation institutional change is a hard feat to achieve. One way to do it could be for the challengers to go head-on with their opponents and attempt to displace the existing budgeting institutions and replace them with PB. Such a confrontation would require a huge support base, similar to what led to the introduction of PB in Porto Alegre in the first place. But this was absent in Fredrikstad. There was no movement or organization demanding $\mathrm{PB}$ from outside the municipal administration nor anyone mobilizing people behind PB once initiated. Given the strictness of the budgeting rules, the strong position of the institutional defenders and the small number of people acting on behalf of the idea, layering became the best available option. PB in Fredrikstad became an addition to representative democracy.

\subsection{A Common Pattern - With One Exception}

Fredrikstad inherited a translation of $\mathrm{PB}$ that was radically different from the version that originated in Porto Alegre. The meaning of PB had changed because it moved to places where the conditions that nurtured it in the first place were absent. This was the case in Europe and in particular in the Nordic countries. In Sweden, Denmark and Finland - and in Fredrikstad - the predominant version of PB was as a makeshift addition to conventional politics, where small sums of money were allocated by special target groups through participatory methods. Although the translators in Fredrikstad slightly modified the version they inherited, they by and large kept it intact. Just as in the other Nordic countries this version fit well with the circumstances under which PB was introduced: there was no movement challenging representative democracy with new values or alternative ways of thinking, the budgeting rules of the established political institutions were strict, the institutional defenders were strong and the change agents were in the minority.

The exception from this pattern tells a great deal. In Reykjavik, Iceland, the only place among the Nordic countries with PB as a regular feature, a scheme called 'Better neighbourhoods' was established in 2011 and has been going on ever since. The scheme basically consists of citizens making proposals to a central website of public works that they wish to see implemented in their neighbourhood and subsequent periodical voting to single out the most popular proposals. The municipality has committed itself to implementing a certain portion of the top demands, and since its inception around 200 public works have been initiated this way. The demands encompass community improvements such as benches, footpaths, lighting, playgrounds etc. (Grímsson \& 
Bjarnason, 2016; Participedia, 2016). Even though Reykjavik's PB concerns only a small share of the budget, the scope of the practice still exceeds that of any other Nordic country. The reason why this was possible was that the institutional defenders in the established political parties had lost support, and thus also their veto power in the municipal council, in the wake of Iceland's financial crash in 2008. In addition, new organizations and movements arose that demanded that citizens should have a direct say in political decisions on Iceland's debt negotiations, general policies at the city level in Reykjavik and even the drafting of a new constitution. Those two conditions were absent in Fredrikstad and in the other Nordic countries at the time of the introduction of PB.

When thinking about institutional change, it is easy to fall into the trap of thinking only of social upheavals that turn the existing social order upside down or the complete replacement of old institutions with new ones. This might close our eyes to other forms of more subtle, almost indistinguishable change, like the addition of $\mathrm{PB}$ to the existing representative political order. In itself, $\mathrm{PB}$ has not changed the way conventional politics is conducted in the Nordic countries. On the other hand, it has been consonant with a series of institutional developments in local democracy. Layering by adding new institutions and practices to the existing political institutions has been the normal way of dealing with claims for increased participation in decisions on and the delivery of services and threats from oppositional movements as well as falling support for representative democracy in the Nordic countries. Councils for immigrants, the disabled and the elderly are found at all levels of governments today as well as representative organs for patients, parents and other user groups in welfare state institutions (Kjølsrød, 2003). Legislation that gives communities the right to participate in planning has been added as a response to claims by oppositional movements on the left (Amdam \& Amdam, 1990) and consumer-oriented management reforms as a response to oppositional movements on the right (Sahlin-Andersson, 2001). In addition, multiple new forms of citizen involvement, participation and deliberation have been initiated by state and local authorities in attempts to counter lower voter-turnouts, falling confidence in government and declining recruitment to political parties (Skivenes \& Eriksen, 2000). This has resulted in what Aars (2012) calls a 'cloudy bundle' of public engagement schemes - especially at the municipal level. Although PB has not changed anything by itself, the added effect of all of these layers has resulted in significant transformations of political institutions in the Nordic countries. Whether this has or has not led to more democracy must be the topic of another chapter. 


\section{References}

Aars, J. (2012). Demokrati som policy: Kommunale tiltak for økt politisk deltakelse. Tidsskrift for samfunnsforskning, 53(04).

Abers, R. N. (2000). Inventing Local Democracy: Grassroots Politics in Brazil. London: Lynne Rienner Publishers.

Amdam, J., \& Amdam, R. (1990). Strategisk og mobiliserande planlegging: Planlegging etter dugnadsmetoden. Oslo: Det norske samlaget.

Avritzer, L. (2006). New Public Spheres in Brazil: Local Democracy and Deliberative Politics. International Journal of Urban and Regional Research, 30(3), 623-637.

Baiocchi, G. (2005). Militants and Citizens: The Politics of Participatory Democracy in Porto Alegre. Standford: Standford University Press.

Baiocchi, G., \& Ganuza, E. (2014). Participatory Budgeting as if Emancipation Mattered. Politics \& Society, 42(1), 29-50.

Baiocchi, G., Heller, P., \& Silva, M. K. (2011). Bootstrapping Democracy: Transforming Local Governance and Civil Society in Brazil. Standford: Standford University Press.

Bregenov-Larsen, A. (2016, 10.06). Borgerbudgettering. Retrieved from http://coi.dk/nyheder/2016/ borgerbudgettering/.

Bystyret i Oslo. (2005). Saksnr. 162/05 i Bystyret: Initativrett (innbyggerinitiativ) om å innføre forsøksordning med deltakende budsjettering. Oslo: Oslo kommune.

Czarniawska, B., \& Sevón, G. (1996). Travels of Ideas. In B. Czarniawska \& G. Sevón (Eds.), Translating Organizational Change (13-48). Berlin: de Gruyter.

de Sousa Santos, B. (1998). Participatory Budgeting in Porto Alegre: Toward a Redistributive Democracy. Politics \& Society, 26(4), 461-510.

Dias, N. (Ed.) (2014). Hope for Democracy: 25 Years of Participatory Budgeting Worldwide. São Brás de Alportel: In Loco Association.

Dolowitz, D. P., \& Marsh, D. (2000). Learning from Abroad: The Role of Policy Transfer in Contemporary Policy-Making. Governance, 13(1), 5-23.

Eidsvold, C. (2014, 24.11). Du bestemmer hvordan torvet skal bli. Fredriksstad Blad.

Eidsvold, C. (2016, 26.10) Spørsmål om deltakende budsjettering i Fredrikstad/Interviewer: S. Legard.

Fedozzi, L. J., Furtado, A., Bassani, V. D. S., et al. (2013). Orçamento participativo de Porto Alegre: Perfil, avaliação e percepções do público participante. Porto Alegre: Gráfica e Editora Hartmann.

Fredrikstad kommune. (2009). Fredrikstadvalget: en bra idé for 200.000. Fredrikstad: Fredrikstad kommune.

Fredrikstad kommune. (2010). Deltakende budsjett i Fredrikstad kommune. Retrieved from https:// www.fredrikstad.kommune.no/Documents/Prosjekter/MSM/deltakende_budsjett.pdf.

Fredrikstad kommune. (2013). Deltagende budsjett. Retrieved from http://fredrikstad.demokratiportalen.se/implan_front.

Fung, A., \& Wright, E. O. (Eds.). (2003). Deepening Democracy: Institutional Innovations in Empowered Participatory Governance. London: Verso.

Gilman, H. R. (2016). Democracy Reinvented: Participatory Budgeting and Civic Innovation in America. Washington, D.C.: Brookings Institution Press.

Goldfrank, B. (2011). Deepening Local Democracy in Latin America: Participation, Decentralization, and the Left. University Park, PA: Penn State University Press.

Gret, M., \& Sintomer, Y. (2005). The Porto Alegre Experiment: Learning Lessons for Better Democracy. London: Zed Books. 
Grímsson, G., \& Bjarnason, R. (2016, 24.10). Better Neighborhoods 2011 to 2016: Participatory Budgeting in Reykjavik. Retrieved from https://docs.google.com/ presentation/d/12RZZG2M3sCYP7-uBhpyl7MytzwLsumXgWcgfpxPewrY/edit\#slide=id. g2a9cb345f_00.

Hardy, C., \& Maguire, S. (2008). Institutional Entrepreneurship. In R. Greenwood, C. Oliver, K. Sahlin \& R. Suddaby (Eds.), The SAGE Handbook of Organisational Institutionalism (198-217). London: SAGE Publications.

Holøien, M. (2015, 20.03). Her bestemmer Ola (5) hvordan parken skal se ut. Fredriksstad blad.

Kallmyr, J., \& Andersson, B. M. (2008, 08.09). Budsjettprosess 2009: Deltakende budsjettering [Letter to Bydel St. Hanshaugen]. Oslo kommune: Byrådsavdeling for velferd og sosiale tjenester.

Kjølsrød, L. (2003). En tjenesteintens velferdsstat. In I. Frønes \& L. Kjølsrød (Eds.), Det norske samfunn. Oslo: Gyldendal.

Kommunesektorens organisasjon. (2010). Hvor godt er lokaldemokratiet?: Kartlegging av innbyggernes og folkevalgtes erfaringer og oppfatninger - resultater fra Fredrikstad kommune. Retrieved from http://www.bedrekommune.no/bedrekommune.no/

filestore/bedrekommuneno/Lokaldemokrati/Rapport_Fredrikstad.pdf.

Kommunesektorens organisasjon. (2013). Idéhefte: Hvordan involvere innbyggerne. Retrieved from http://www.ks.no/globalassets/idehefte-hvordan-involvere-innbyggerene.pdf?id=16500.

Latour, B. (1986). The Power of Association. In J. Law (Ed.), Power, Action and Belief (Vol. 264-280). London: Routledge and Kegan Paul.

Latour, B. (1991). Technology is Society made Durable. In J. Law (Ed.), A Sociology og Monsters: Essays on Power, Technology and Domination (103-131). London: Routledge.

Lysbakken, A., \& Skjerve, I. (2009). Deltakerne: En reise i demokratiets framtid. Oslo: Forlaget Manifest.

Mahoney, J., \& Thelen, K. (2010). A Theory of Gradual Institutional Change. In J. Mahoney \& K. Thelen (Eds.), Explaining Institutional Change: Ambiguity, Agency and Power. Cambridge: Cambridge University Press.

Marquetti, A. (2008). Orçamento participativo, redistribuição e finanças municipais: a experiência de Porto Alegre entre 1989 e 2004. In A. Marquetti, G. A. d. Campos \& R. Pires (Eds.), Democracia participativa e redistribuição: análise de experiências de orçamento participativo. São Paulo: Xamã.

Marsh, D., \& Sharman, J. C. (2009). Policy Diffusion and Policy Transfer. Policy Studies, 30(3), 269-288.

Mukhtarov, F. (2014). Rethinking the Travel of Ideas: Policy Translation in the Water Sector. Policy \& Politics, 42(1), 71-88.

Oikkonen, H. (2012). Participatory Budgeting: Helsinki City Library. Paper presented at the IFLA World Library and Information Congress, Helsinki. Retrieved from http://www.slideshare.net/ HeiniOikkonen/participatorybudgeting-iflahelsinki2012?ref=http://osallistuvabudjetointi.fi/ participatory-budgeting-taking-first-steps-in-finland/

Oliveira, O. P. d., \& Allegretti, G. (2013). Following a World Traveller: A Comparative Approach to Participatory Budgeting Transfers. Paper presented at the European Consortium for Political Research General Conference, Bordeaux. Retrieved from https://ecpr.eu/Events/PaperDetails. aspx?Paper $I D=4607 \&$ EventID=5.

Participedia. (2016). Electronic Participatory Budgeting in Iceland. Retrieved from https:// https:// participedia.net/en/cases/electronic-participatory-budgeting-iceland.

Peck, J., \& Theodore, N. (2015). Fast Policy: Experimental Statecraft at the Thresholds of Neoliberalism. Minneapolis: Minnesota University Press.

Regjeringen Stoltenberg II. (2009). Politisk plattform for flertallsregjeringen utgått av Arbeiderpartiet, Sosialistisk Venstreparti og Senterpartiet. Oslo: Statsministerens kontor. 
Regjeringen.no. (2015). Nærdemokrati i Fredrikstad. Retrieved from https://www.regjeringen.no/no/ tema/kommuner-og-regioner/kommunereform/Verktoy/lokaldemokrati/del-a/nardemokrati-ifredrikstad/id2424160/.

Røvik, K. A. (2016). Knowledge Transfer as Translation: Review and Elements of an Instrumental Theory. International Journal of Management Reviews, 18(3), 290-310.

Sahlin-Andersson, K. (1996). Imitating by Editing Success: The Construction of Organizational Fields. In B. Czarniawska \& G. Sevón (Eds.), Translating Organizational Change. Berlin: de Gruyter.

Sahlin-Andersson, K. (2001). National, International and Transnational Constructions of New Public Management. In T. Christensen \& P. Lægreid (Eds.), New Public Management: The Transformation of Ideas and Practice. Hampshire: Ashgate.

Sahlin, K., \& Wedlin, L. (2008). Circulating Ideas: Imitation, Translation and Editing. In R. Greenwood, C. Oliver, K. Sahlin, \& R. Suddaby (Eds.), The SAGE Handbook of Organisational Institutionalism. London: SAGE Publications.

Scheuer, J. D. (2008a). Convergent and Divergent Processes of Change in Organizations: Exploring Change as Translation in the Encounter of Idea and Practice. In S. Scheuer \& J. D. Scheuer (Eds.), The Anatomy of Change: A Neo-Institutionalist Perspective of Change (107-137). Copenhagen: Copenhagen Business School Press.

Scheuer, J. D. (2008b). Intervention, Implementation and Translation as Metaphors of Change in Healthcare and Public Sector Organizations. In S. Scheuer \& J. D. Scheuer (Eds.), The Anatomy of Change: A Neo-Institutionalist Perspective of Change (139-180). Copenhagen: Copenhagen Business School Press.

Scott, W. R. (1995). Institutions and Organizations. Newbury Park: Sage Publications.

Simmons, B. A., Dobbin, F., \& Garrett, G. (2006). Introduction: The International Diffusion of Liberalism. International Organization, 60(4), 781-810.

Sintomer, Y., Herzberg, C., \& Röcke, A. (2008). Participatory Budgeting in Europe: Potentials and Challenges. International Journal of Urban and Regional Research, 32(1), 164-178.

Skivenes, M., \& Eriksen, E. O. (2000). Nye deltagelsesformer og demokratisk medvirkning. Bergen: LOS-Senteret.

Sveriges Kommuner och Landsting. (2010). Participatory Budgeting: Fact Sheet the 'Citizen Dialogue' Project. Stockholm: Sveriges Kommuner och Landsting.

Sveriges Kommuner och Landsting. (2011). Medborgarbudget i Sverige, Europa och världen. Stockholm: Sveriges Kommuner och Landsting.

Syversen, M. N. (2013, 09.10). Hvordan blir den nye skatehallen? Fredriksstad blad.

Tarrow, S. (1998). Framing Contention. In S. Tarrow (Ed.), Power in Movement: Social Movements and Contentious Politics. Cambridge: Cambridge University Press.

Wampler, B. (2007). Participatory Budgeting in Brazil: Contestation, Cooperation and Accountability. University Park: The Pennsylvania State University Press.

Wampler, B. (2012). Participatory Budgeting: Core Principles and Key Impacts. Journal of Public Deliberation, 8(2), 1-13.

Wright, E. O. (2010). Envisioning Real Utopias. London: Verso.

Wæraas, A., \& Agger Nielsen, J. (2015). Translation Theory 'Translated': Three Perspectives on Translation in Organizational Research. Ås: Norwegian University of Life Sciences.

Wæraas, A., \& Sataøen, H. L. (2014). Trapped in Conformity? Translating Reputation Management into Practice. Scandinavian Journal of Management, 30(2), 242-253.

Ystgaard, D. H. (2013). Bygger skatehall på dugnad. Retrieved from http://interreg.no/2013/11/ bygger-skatehall-pa-dugnad/. 